\title{
Evaluasi Kesesuaian Lahan untuk Pendugaan Debit Mata Air Menggunakan Metode Inferensia Fuzzy Sugeno
}

\section{Land Suitability Evaluation for The Prediction of Water Spring Discharge Rate using Sugeno Fuzzy Inference Method}

\author{
MEUTHIA RACHMANIAH ${ }^{1}$, WINDA GIAM $^{1}$, ROH SANTOSO BUDI WASPODO $^{2}$
}

\begin{abstract}
Abstrak
Penelitian ini dilakukan untuk mengidentifikasi tingkat debit sumber mata air berkualitas. Debit mata air dihitung berdasarkan jumlah tanaman, tingkat air tanah, dan sudut topografi dengan menggunakan metode inferensia fuzzy Sugeno. Untuk memverifikasi analisis dan hasilnya, telah dikembangkan aplikasi yang menggunakan aplikasi APMA-Fuzzy. Data survei lapangan yang digunakan diperoleh dari desa Balumbangjaya dan Situgede. Selanjutnya, data dianalisis dengan menggunakan fungsi keanggotaan fuzzy Sugeno. Aturan fuzzy dibuat dengan bantuan seorang ahli mata air. Konsep aturan adalah bahwa semakin besar nilai masukan, semakin besar pula nilai keluarannya. Analisis canggih dilakukan untuk menentukan akurasi dan reliabilitas metode fuzzy Sugeno yang digunakan dalam aplikasi. Hasilnya adalah bahwa setiap data dari tiga belas data survey lapangan memiliki akurasi lebih dari 50\%, sedangkan akurasi rata-ratanya adalah 77,53\%. Dengan demikian, aplikasi yang dikembangkan dalam penelitian ini layak dan aturan yang telah dibuat juga terbukti benar.
\end{abstract}

Kata kunci: fungsi keanggotaan, fuzzy Sugeno, mata air, tingkat debit.

\begin{abstract}
This research is aimed toward identifying source of quality water springs discharge rate. The rate was calculated based on the number of plants, ground water level, and topography angle using the Sugeno fuzzy inference method. To verify the analysis and its results, an application using APMA-Fuzzy software has been developed. The field survey data were obtained from Balumbang jaya and Situgede villages. Further, the data were analyzed using Sugeno fuzzy membership function. Following that, a water spring expert provided assistances in rules generation. The concept of the rule was that the greater the input value, the greater the value of its output. Advanced analysis was carried out to determine the accuracy and reliability of Sugeno fuzzy method used. The results were that each data from the thirteen field survey data has an accuracy of more than 50\%, while the average accuracy was 77.53\%. Thus, application developed in this research is feasible and the rules generated are also proved to be correct.
\end{abstract}

Keywords: Sugeno fuzzy, water spring, membership function, discharge rate.

\section{PENDAHULUAN}

World Resources Institute (Amerika Serikat) memperkirakan $41000 \mathrm{~km}^{3}$ air per tahun mengalir dari daratan ke lautan. Sebanyak $27000 \mathrm{~km}^{3}$ kembali ke laut sebagai limpasan banjir yang tidak dapat ditangkap, $5000 \mathrm{~km}^{3}$ melalui area yang tidak berpenghuni dan kembali lagi ke laut. Sejumlah tertentu tertahan di daratan, di antaranya terserap oleh tanaman yang jumlahnya belum dapat diketahui secara pasti. Lebih kurang $9000 \mathrm{~km}^{3}$ air tawar siap digunakan oleh manusia di bumi. Namun, jumlah air yang kualitasnya baik makin sulit ditemukan (Said 2010).

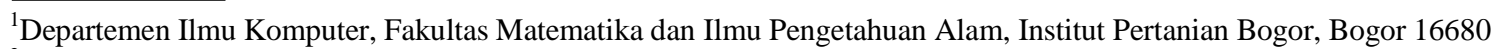

${ }^{2}$ Departemen Teknik Sipil dan Lingkungan, Fakultas Teknologi dan Pertanian, Institut Pertanian Bogor, Bogor 16680

*Penulis korespondensi: Tel/Faks: 0251-8625584; Surel: titailkom@ yahoo.com
} 
Mata air yang kurang terawat, terjaga, dan terpelihara dengan maksimal menyebabkan kualitas sumber daya air menurun, mata air yang hilang atau tidak dapat digunakan lagi. Beberapa contoh antara lain penurunan debit air di mata air alur Kali Pabelan, Magelang, yang disebabkan banjir lahar dingin pasca letusan Gunung Merapi (Joewono 2011), di Kota Salatiga yang disebabkan berkurangnya daerah resapan air (Nugrahanti dan Joewono 2011), dan proyek jalan tol UngaranBawen di Semarang yang menggusur tiga sumber mata air (Herusansono dan Suprihadi 2011). Penelitian ini merupakan alat bantu untuk proses pencarian mata air yaitu dengan membangun suatu aplikasi sistem pakar. Sistem yang dibangun dapat menduga debit mata air pada suatu wilayah dengan parameter input jumlah tanaman, tinggi muka air tanah, dan besar sudut topografi.

\section{METODE}

Metode yang digunakan pada penelitian ialah metode inferensia fuzzy Sugeno. Beberapa alasan penggunaan metode fuzzy adalah karena metode fuzzy mempunyai beberapa kelebihan antara lain logika fuzzy sangat fleksibel dan memiliki toleransi terhadap data-data yang tidak tepat. Selain itu logika fuzzy juga dapat membangun dan mengaplikasikan pengalaman para pakar secara langsung tanpa harus melalui proses pelatihan (Kusumadewi 2002). Alur penelitian dapat dilihat pada Gambar 1.

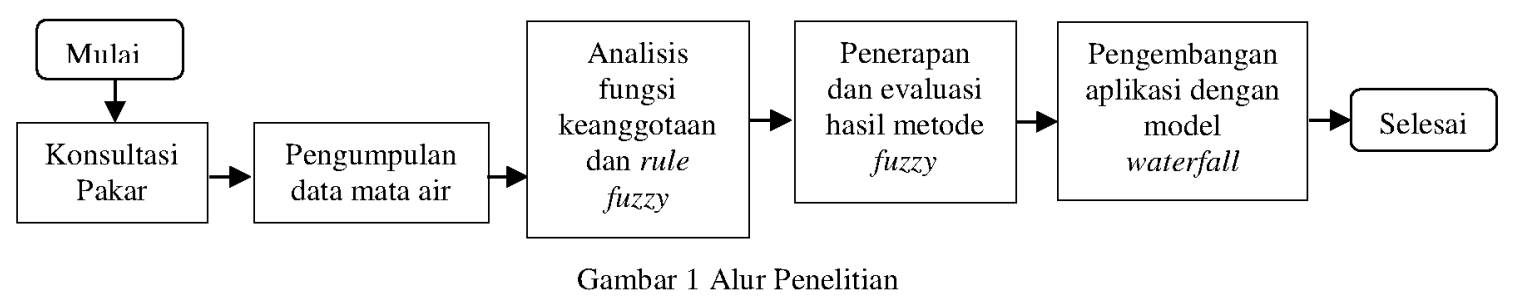

\section{Konsultasi dengan Pakar}

Pakar sumberdaya air yang dilibatkan adalah juga peneliti dalam penelitian ini. Pakar berasal dari Departemen Teknik Sipil dan Lingkungan, Fakultas Teknologi Pertanian, Institut Pertanian Bogor.

\section{PengumpulanData Mata Air}

Data yang dikumpulkan adalah data jumlah tanaman dan data koordinat Global Positioning System (GPS). Data koordinat GPS diolah menjadi data tinggi muka air tanah dan sudut topografi dengan metode interpolasi linier pada garis kontur peta pada bantuan peta rupa bumi berskala 1:25.000. Selanjutnya data koordinat GPS diolah menjadi data besar sudut topografi melalui rumus dasar arc sinus trigonometry pada segitiga dengan sisi miring segitiga. Asumsi yang dipakai ialah jarak antara garis kontur yang berdekatan pada lapangan dan melalui titik GPS, dan sisi depan sudut segitiga adalah selisih antara tinggi dua garis kontur yang berdekatan dan melalui titik GPS.

\section{Analisis Fungsi Keanggotaan dan Rule Fuzzy}

Konsep rule fuzzy yang digunakan ialah semakin tinggi level fungsi keanggotaan input fuzzy, maka semakin tinggi pula level fungsi keanggotaan output fuzzy. Fungsi keanggotaan input dan fungsi keanggotaan output didapat dari hasil analisis data survei lapangan.

Fungsi keanggotaan input menggunakan fungsi keanggotaan bentuk segitiga dengan tiga nilai linguistik untuk ketiga input. Batas-batas fungsi keanggotaan input diambil dari nilai maksimum, nilai tengah, dan nilai minimum data. Fungsi keanggotaan output digunakan fungsi singleton (konstanta) karena metode fuzzy yang digunakan adalah fuzzy Sugeno orde nol. Fungsi keanggotaan output dibagi menjadi tujuh singleton dengan fungsi keanggotaan pertama adalah debit mata air minimum dari seluruh data. Lalu fungsi keanggotaan ketujuh adalah debit air 
maksimum dari seluruh data dan fungsi keanggotaan kedua sampai keenam dibagi sama rata dari debit mata air maksimum dikurangi debit mata air minimum.

Fungsi keanggotaan output fuzzy dibagi menjadi tujuh level dengan cara menggabungkan kombinasi banyak level fungsi keanggotaan input dengan asumsi bahwa pengaruh tiap input fuzzy pada output fuzzy (debit mata air dugaan) adalah sama. Ketika terdapat satu fungsi keanggotaan input fuzzy naik sebanyak $x$ level, level fungsi keanggotaan output juga naik sebanyak $x$ level. Jika terdapat dua fungsi keanggotaan input fuzzy yang naik sebanyak $x$ level untuk fungsi keanggotaan input fuzzy pertama dan sebanyak $y$ level untuk fungsi keanggotaan input fuzzy kedua maka level fungsi keanggotaan output juga akan naik sebanyak $(x+y)$ level. Jika terdapat tiga fungsi keanggotaan input fuzzy yang naik sebanyak $x$ level untuk fungsi keanggotaan input fuzzy pertama dan sebanyak $y$ level untuk fungsi keanggotaan input fuzzy kedua dan sebanyak $z$ level untuk fungsi keanggotaan input fuzzy ketiga maka level fungsi keanggotaan output juga akan naik sebanyak $(x+y+z)$ level.

\section{Penerapan dan Evaluasi Hasil Metode Fuzzy}

Metode fuzzy Sugeno menghasilkan output berupa nilai crisp dan bukan nilai linguistik. Penerapan fuzzy dilakukan dalam tiga tahap yaitu tahap fuzzification, inference, dan defuzzification.Tahap fuzzification menggunakan fungsi keanggotaan bentuk segitiga. Tahap inference memakai operator AND (prinsip logical connectives conjunction) dan menggunakan tabel aturan berisi 27 aturan ( 3 level linguistik jumlah tanaman x 3 level linguistik tinggi muka air tanah x 3 level linguistik sudut topografi). Tahap defuzzification menggunakan metode weighted average. Evaluasi akurasi fuzzy dilakukan dengan menggunakan formula kesalahan/galat. Hasil akhir dari evaluasi akurasi untuk tiap data didapat dari persamaan:

$$
\text { Akurasi }=100 \% \text { - galat/error }
$$

\section{Pengembangan Aplikasi dengan Model Waterfall}

Tahapan pengembangan aplikasi terdiri atas analisis dan definisi kebutuhan, desain sistem dan perangkat lunak, implementasi dan uji unit, integrasi dan uji sistem, serta operasi dan pemeliharaan. Tahap operasi dan pemeliharaan tidak dilakukan karena keterbatasan waktu.

\section{HASIL DAN PEMBAHASAN}

\section{Konsultasi dengan Pakar}

Hasil konsultasi dengan pakar diperoleh tiga karakteristik lahan yaitu jumlah tanaman, tinggi muka air tanah, dan sudut topografi sebagai parameter dari proses pendugaan debit mata air. Dalam pengukuran jumlah tanaman dilakukan pembatasan ruang pengukuran dengan diameter sepuluh meter dari mata air yang diukur. Jumlah tanaman diukur berdasarkan satuan batang. Tinggi muka air tanah diukur berdasarkan kontur pada peta dengan satuan meter di atas permukaan laut. Teknik pengukuran debit mata air menggunakan gelas ukur dengan satuan milliliter. Waktu untuk menampung air dalam gelas ukur juga diukur menggunakan stopwatch dengan satuan detik. Debit mata air didapat dari volume mata air dibagi dengan waktu.

Karakteristik lahan lainnya yang dapat mempengaruhi debit mata air diantaranya produktivitas lapisan batuan yang dapat mengalirkan air (akuifer) dan luas daerah resapan air. Pada penelitian ini level/tingkat debit mata air dibagi berdasarkan data hasil survei lapangan:

- $<14.73 \mathrm{ml} / \mathrm{s}$ (level rekomendasi rendah)

- >=14.73 ml/s dan <=23.36 ml/s (level rekomendasi sedang)

- $<23.36 \mathrm{ml} / \mathrm{s}$ (level rekomendasi tinggi)

Pada penelitian ini ada dua asumsi yang dipakai, yaitu:

1) Asumsi untuk penentuan level fungsi keanggotaan output fuzzy ialah pengaruh dari tiap input fuzzy pada output fuzzy (debit mata air dugaan) adalah sama. 
2) Asumsi pada proses pengukuran debit air pada daerah resapan air yang diteliti, pengukuran hanya dilakukan pada air yang keluar melalui mata air. Air dalam tanah tidak diukur karena tidak selalu hanya mengalir pada satu mata air melainkan bisa juga mengalir ke sungai, laut, ataupun mata air yang lain (Gambar 2, Anonim 2001).

\section{Pengumpulan Data Mata Air}

Pengumpulan data dilakukan melalui survei lapangan langsung di Kelurahan Balumbangjaya dan Kelurahan Situgede. Pengolahan data GPS menjadi data tinggi muka air tanah dan sudut topografi memakai bantuan peta rupa bumi Balumbangjaya dan Situgede skala 1:25.000. Proses penghitungan pengolahan data GPS ini akan diilustrasikan dengan contoh sampel L1 dan L7 pada Tabel 1. Pada L1, jarak dari kontur 200 meter ke titik sampel pada peta adalah $8.6 \mathrm{~cm}$ dan jarak antara titik sampel ke titik kontur 150 meter pada peta adalah $4.7 \mathrm{~cm}$ seperti yang diperlihatkan pada Gambar 3.

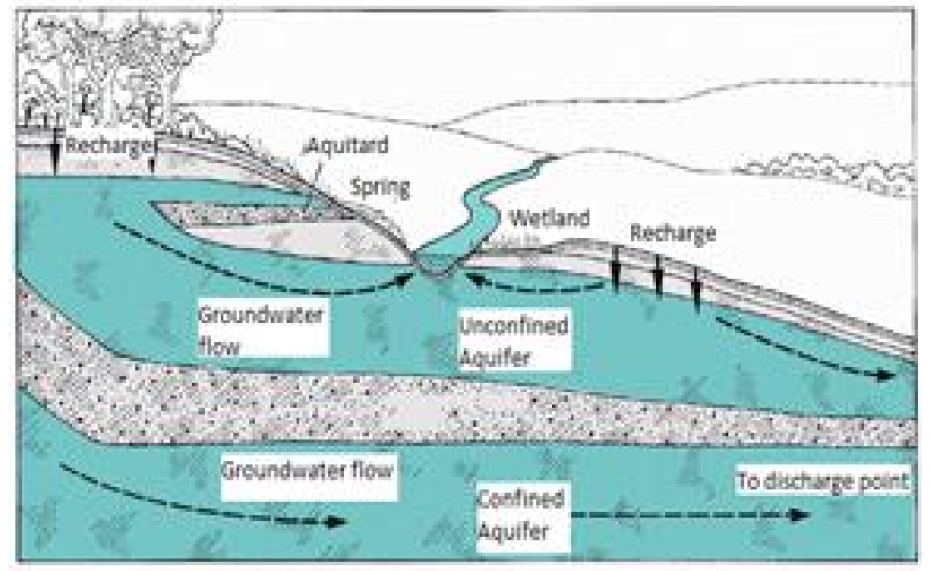

Gambar 2 Ilustrasi aliran air tanah

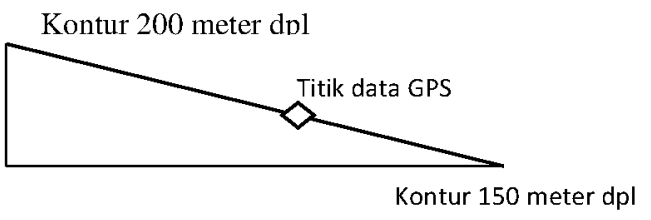

Gambar 3 Interpolasi Linier untuk mencari tinggi mula air tanah

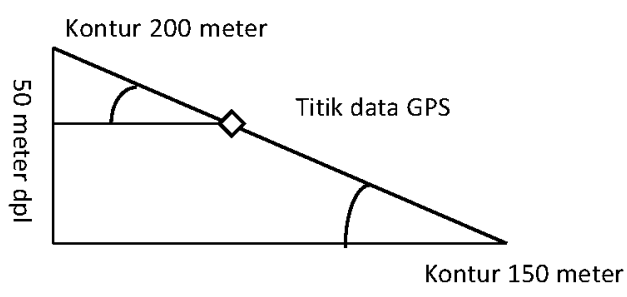

Gambar 4 Ilustrasi pengolahan data GPS menjadi data sudut topografi

Tinggi muka air tanah ("y") pada titik sampel tersebut dapat dicari dengan persamaan:

$$
y=\left(\frac{4.7 \mathrm{~cm}}{4.7 \mathrm{~cm}+8.6 \mathrm{~cm}} \times(200-150) \text { meter }\right)+150 \text { meter }=167.67 \text { meter }
$$

Pada sampel kedua yaitu L7, jarak dari kontur 200 meter ke titik sampel pada peta adalah $15.5 \mathrm{~cm}$ dan jarak antara titik sampel ke titik kontur 150 meter adalah $0.3 \mathrm{~cm}$ (Gambar 3). Maka tinggi muka air tanah (" $y$ ") pada titik sampel tersebut dapat dicari dengan persamaan berikut:

$$
y=\left(\frac{0.3 \mathrm{~cm}}{0.3 \mathrm{~cm}+15.5 \mathrm{~cm}} \times(200-150) \text { meter }\right)+150 \text { meter }=150.94 \text { meter }
$$

Adapun ilustrasi pengolahan data GPS menjadi data sudut topografi dapat dilihat pada Gambar 4. Tinggi 50 meter didapat dari tinggi kontur 200 meter dikurangi tinggi kontur 150 meter. Sudut $\alpha$ sama besar dengan sudut $\beta$. Pada sampel L1, jarak antara kontur 200 meter dan kontur 150 
meter pada peta yang melewati titik sampel adalah 13.3 sentimeter $(0.13$ meter $)$ maka perhitungan sudut topografi pada titik sampel pertama adalah sebagai berikut:

$$
\alpha=\beta=\arcsin \left(\frac{50 \text { meter }}{0.13 \text { meter } \times 25000}\right)=0.86^{\circ}
$$

dengan $\alpha$ adalah sudut topografi pada titik sampel pertama dan angka 25000 pada perhitungan didapat dari skala peta rupa bumi Kelurahan Balumbangjaya.

Pada sampel L7, jarak antara kontur 200 meter dan kontur 150 meter pada peta yang melewati titik sampel adalah 15.8 sentimeter ( 0.15 meter). Dengan demikian, perhitungan sudut topografi pada titik sampel kedua sebagai berikut:

$$
\alpha=\beta=\arcsin \left(\frac{50 \text { meter }}{0.15 \text { meter } \times 25000}\right)=0.73^{\circ}
$$

dengan $\alpha$ adalah sudut topografi pada titik sampel kedua dan angka 25000 pada perhitungan didapat dari skala peta rupa bumi Kelurahan Situgede.

\section{Fungsi Keanggotaan dan Rule Fuzzy}

Fungsi keanggotaan inputL1 (sampel) terdiri atas tinggi muka air tanah (Gambar 5), jumlah tanaman (Gambar 6), dan sudut topografi (Gambar 7). Dimana: R (Rendah) diambil dari nilai input minimum, S (Sedang) diambil dari nilai input tengah dari, dan $\mathrm{T}$ (Tinggi) diambil dari nilai input maximum dari seluruh data survei lapangan.

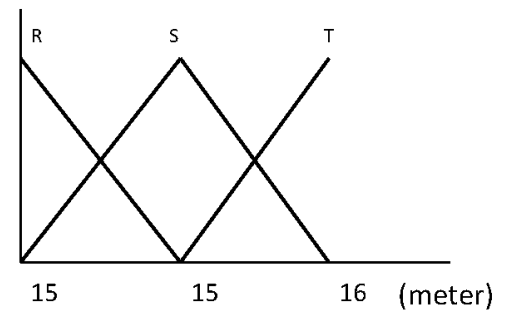

Gambar 5 Fungsi keanggotaan tinggi muka air tanah

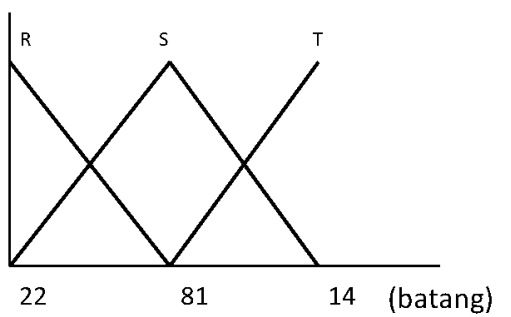

Gambar 6 Fungsi keanggotaan jumlah tanaman

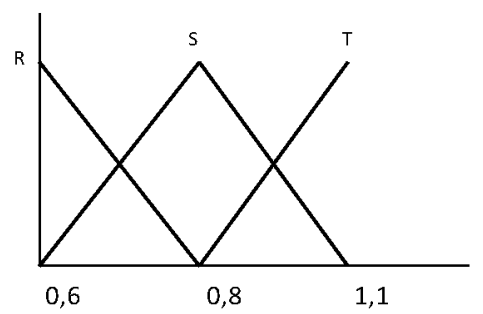

Gambar 7 Fungsi keanggotaan sudut topografi

Data survei lapangan menghasilkan fungsi keanggotaan output 1 sampai output 7 dalamsatuan milliliter per detik. Nilai fungsi keanggotaan dibagi sama rata dari debit air maksimum dikurangi debit air minimum. Adapun rule fuzzy yang digunakan disajikan pada Tabel 2.

Tabel 2 Rule Fuzzy

\begin{tabular}{c|cccccccccc}
\hline \multirow{4}{*}{$\begin{array}{c}\text { Sudut } \\
\text { Topografi }\end{array}$} & \multicolumn{1}{c}{ R } & \multicolumn{1}{c}{\begin{tabular}{c} 
Jumlah Tanaman \\
\cline { 2 - 12 }
\end{tabular}} & $\begin{array}{c}\text { Tingi Muka Air } \\
\text { Tanah }\end{array}$ & \multicolumn{4}{c}{$\begin{array}{c}\text { Tinggi Muka Air } \\
\text { Tanah }\end{array}$} & \multicolumn{3}{c}{$\begin{array}{c}\text { Tinggi Muka Air } \\
\text { Tanah }\end{array}$} \\
\cline { 2 - 13 } & $\mathrm{R}$ & $\mathrm{S}$ & $\mathrm{T}$ & $\mathrm{R}$ & $\mathrm{S}$ & $\mathrm{T}$ & $\mathrm{R}$ & $\mathrm{S}$ & $\mathrm{T}$ \\
\hline $\mathrm{R}$ & 1 & 2 & 3 & 2 & 3 & 4 & 3 & 4 & 5 \\
\hline $\mathrm{S}$ & 2 & 3 & 4 & 3 & 4 & 5 & 4 & 5 & 6 \\
\hline $\mathrm{T}$ & 3 & 4 & 5 & 4 & 5 & 6 & 5 & 6 & 7 \\
\hline
\end{tabular}

\section{Keterangan:}

1: output_1=6.09 ml/s

2: output_2=10.41 ml/s

3: output_3=14.72 $\mathrm{ml} / \mathrm{s}$

4: output_4=19.04 ml/s

5: output_5=23.36 ml/s

6: output_6=27.68 m1/s

7: output_7=32 ml/s

\section{Penerapan dan Evaluasi Hasil Metode Fuzzy}

Penerapan fuzzy terbagi tiga tahap yaitu fuzzification, inference, dan defuzzification.Pada artikel ini akan diberikan contoh perhitungan fuzzy dengan sampel L1 pada Tabel 1. Lokasi L1 berada di Kelurahan Balumbangjaya dengan jumlah tanaman 52 batang, tinggi muka air tanah 167.67 meter, dan sudut topografi 0.86 derajat. 


\section{Fuzzification}

Tahap ini menghitung nilai derajat keanggotaan input untuk tinggi muka air tanah (Gambar 8), jumlah tanaman (Gambar 9), dan sudut topografi (Gambar 10). Untuk menghitung derajat keanggotaan tinggi muka air tanah digunakan bentuk fungsi keanggotaan segitiga.

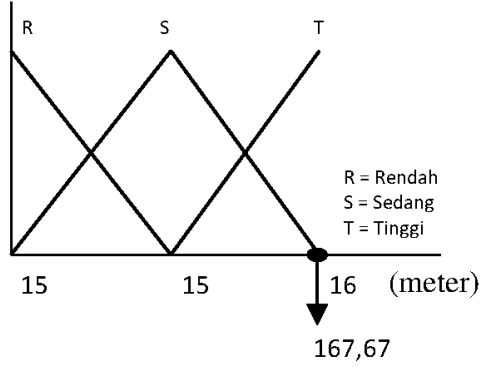

Gambar 8 Ilustrasi perhitungan fuzzification input tinggi muka air tanah

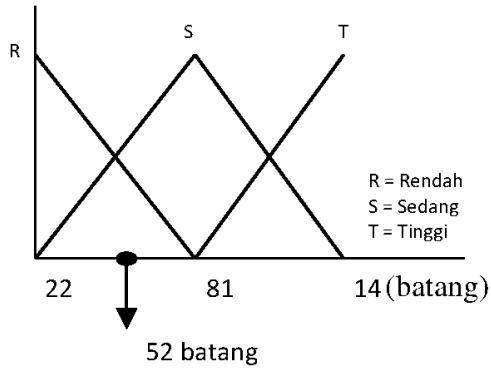

Gambar 9 Ilustrasi perhitungan fuzzification input jumlah tanaman

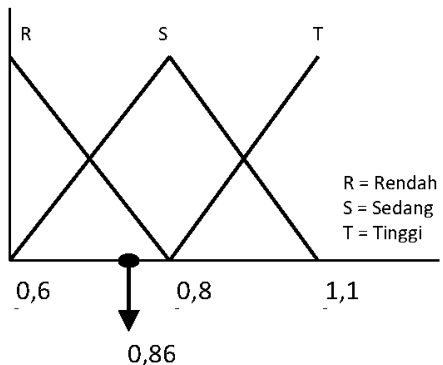

Gambar 10 Ilustrasi perhitungan fuzzification input sudut topografi

Tinggi muka air tanah L1 ialah 167.67 meter tepat berada di batas fungsi keanggotaan tinggi muka air tanah 'Tinggi' (Gambar 8). Jadi, derajat keanggotaan tinggi muka air tanah selain "Tinggi" adalah nol. Perhitungannya adalah sebagai berikut (W sebagai simbol derajat keanggotaan):

$$
\begin{aligned}
& \text { W_tinggiMukaAirTanah_rendah }=0 \\
& \text { W_tinggiMukaAirTanah_sedang }=0 \\
& \text { W_tinggiMukaAirTanah_Tinggi }=\frac{\mathbf{1 6 7 . 6 7 - 1 5 9 . 0 2}}{\mathbf{1 6 7 . 6 7 - 1 5 9 . 0 2}}=1
\end{aligned}
$$

Jumlah tanaman L1 ialah 52 batang dan berada di antara batas fungsi keanggotaan jumlah tanaman "Rendah" dan "Sedang" (Gambar 9). Derajat keanggotaan jumlah tanaman selain "Rendah" dan "Sedang" adalah nol. Perhitungannya adalah sebagai berikut dengan W sebagai simbol derajat keanggotaan.

$$
\begin{gathered}
\text { W_jumlahTanaman_rendah }=\frac{81-52}{81-22}=0.49 \\
\text { W_jumlahTanaman_sedang }=\frac{52-22}{81-22}=0.51 \\
\text { W_jumlahTanaman_tinggi }=0
\end{gathered}
$$

Sudut topografi $\mathrm{L} 1$ ialah $0.86^{\circ}$ dan berada di antara batas fungsi keanggotaan sudut topografi "Rendah" dan "Sedang" (Gambar 10). Derajat keanggotaan sudut topografi selain "Rendah" dan "Sedang"adalah nol. Hasil fuzzificationpada lokasi satu (L1) sampai lokasi empat (L4) dihitung dengan formula sebagai berikut:

$$
\begin{aligned}
& \text { W_sudutTopografi_rendah }=\frac{0.89-0.86}{0.89-0.67}=0.14 \\
& \text { W_sudutTopografi_sedang }=\frac{0.86-0.67}{0.89-0.67}=0.86 \\
& \text { W_sudutTopografi_tinggi }=0
\end{aligned}
$$

\section{Inference}

Pada tahap inference, fuzzy input hasil fuzzification kemudian diolah memakai operator AND (prinsip logical connectives conjunction) dan menggunakan Tabel 2. Berikut adalah contoh perhitungan tahap inference pada sampel lokasi satu (L1) dari Tabel 1. Rule yang dipakai pada sampel L1 berjumlah empat buah karena yang dipengaruhi oleh derajat keanggotaan input hasil tahap fuzzification pada sampel satu juga berjumlah empat buah. Rule pada Tabel 2 yang terpengaruh merupakan kombinasi dari nilai linguistik fungsi keanggotaan input hasil tahap fuzzification sampel lokasi satu (L1) yang derajat keanggotaannya tidak bernilai nol. 
Nilai-nilai $\mathrm{R}, \mathrm{S}$, dan $\mathrm{T}$ yang dipilih adalah nilai linguistik tiap fungsi keanggotaan input sampel L1 hasil fuzzification $=0.49=0.51=0.14=0.86$. Selanjutnya, untuk jumlah tanaman (JT), nilai linguistik yang ditandai hanya "Rendah" dan "Sedang". Untuk tinggi muka air tanah (AT), nilai linguistik yang ditandai hanya "Tinggi", dan untuk sudut topografi (ST), nilai linguistik yang ditandai hanya "Rendah" dan "Sedang". Kombinasi ini menghasilkan empat rule yang berpengaruh untuk sampel L1, yaitu:

- Jika JT "Rendah", AT "Tinggi”, dan ST"Rendah", fungsi keanggotaan output debit mata air adalah output_3.

- Jika JT "Rendah", AT “Tinggi”, dan ST "Sedang”, fungsi keanggotaan output debit mata air adalah output_4.

- Jika JT “Sedang”, AT “Tinggi”, dan ST "Rendah”, fungsi keanggotaan output debit mata air adalah output_4.

- Jika JT "Sedang", AT “Tinggi”, dan ST "Sedang”, fungsi keanggotaan output debit mata air adalah output_5.

Tahap inference melibatkan operator AND pada rule untuk mendapatkan nilai derajat keanggotaan fungsi keanggotaan output. Perhitungan untuk mendapatkan nilai derajat keanggotaan fungsi keanggotaan output pada sampel L1 yaitu dengan cara mengambil nilai derajat keanggotaan minimum dari ketiga input untuk tiap rule yang dipengaruhi. Nilai minimum ini akan menjadi nilai derajat keanggotaan fungsi keanggotaan output. Hasilnya adalah seperti berikut ini:

- Jika JT "Rendah" (W = 0.49), AT "Tinggi” (W = 1), dan ST "Rendah" (W= 0.14), level debit mata air adalah output_3. Derajat keanggotaan output_3 = minimum $(0.49,1,0.14)=0.14$

- Jika JT "Rendah" (W = 0.49), AT “Tinggi” (W = 1), dan ST "Sedang" (W = 0.86), debit mata air adalah output_4. Derajat keanggotaan output_4 $=$ minimum $(0.49,1,0.86)=0.49$

- Jika JT "Sedang” (W = 0.51), AT "Tinggi” (W=1), dan ST "Rendah" (W=0.14), debit mata air adalah output_4. Derajat keanggotaan output_4 $=$ minimum $(0.51,1,0.14)=0.14$

- Jika JT "Sedang" (W = 0.51), AT “Tinggi” ( $\mathrm{W}=1)$, dan ST "Sedang” (W = 0.86), debit mata air adalah output_5. Derajat keanggotaan output_5 = minimum $(0.51,1,0.86)=0.51$

\section{Defuzzification}

Tahap terakhir dalam sistem fuzzy adalah defuzzification. Fungsi keanggotaan output dan fuzzy output hasil inference diolah menggunakan metode defuzzification weighted average sehingga menghasilkan crisp output. Crisp output adalah debit mata air dugaan sebagai hasil akhir fuzzy. Untuk sampel L1 proses perhitungan metode defuzzification weighted average adalah jumlah dari semua nilai fungsi keanggotaan output (lihat Tabel 4) dikali dengan derajat keanggotaan output.

$$
\begin{aligned}
\text { crisp output }= & (0.14 \times 14.72 \mathrm{ml} / \mathrm{s})+(0.49 \times 19.04 \mathrm{ml} / \mathrm{s})+(0.14 \times 19.04 \mathrm{ml} / \mathrm{s})+ \\
& (0.51 \times 23.36 \mathrm{ml} / \mathrm{s}) \\
= & 20.26 \mathrm{ml} / \mathrm{s}
\end{aligned}
$$

Persentase keakuratan debit mata air dugaan hasil fuzzy dengan debit mata air hasil survei lapangan dihitung menggunakan formula kesalahan/galat. Sebagai contoh, perhitungan persentase akurasi pada sampel L1adalah sebagai berikut (dengan $21.33 \mathrm{ml} / \mathrm{s}$ adalah debit air hasil survei lapangan dan $20.26 \mathrm{ml} / \mathrm{s}$ adalah debit air dugaan hasil fuzzy):

$$
\text { Error L1 }=\frac{|20.26 \mathrm{ml} / \mathrm{s}-21.33 \mathrm{ml} / \mathrm{s}|}{21.33 \mathrm{ml} /} \times 100 \%=5.02 \%
$$

Akurasi L1 $=100 \%$ - Error L1 $=94.98 \%$

Grafik perbandingan debit mata air di lapangan dengan debit mata air hasil fuzzy system dari seluruh data survei lapangan dapat dilihat pada Gambar 11; sedangkan grafik perbandingan akurasi dari seluruh data survei lapangan dapat dilihat pada Gambar 12. Dari seluruh data survei terdapat 
tiga lokasi dengan persentase akurasi $\pm 90 \%$, dua lokasi $\pm 80 \%$, tiga lokasi $\pm 70 \%$, empat lokasi \pm $60 \%$, dan satu lokasi $59.14 \%$. Lima lokasi dengan akurasi di bawah $70 \%$ diperkirakan terjadi dari dua kemungkinan.Kemungkinan pertama yaitu adanya salah pengukuran ketika survei lapangan. Kemungkinan kedua yaitu penentuan rule, jumlah, batas-batas, dan bentuk fungsi keanggotaan metode fuzzy Sugeno yang kurang optimal.

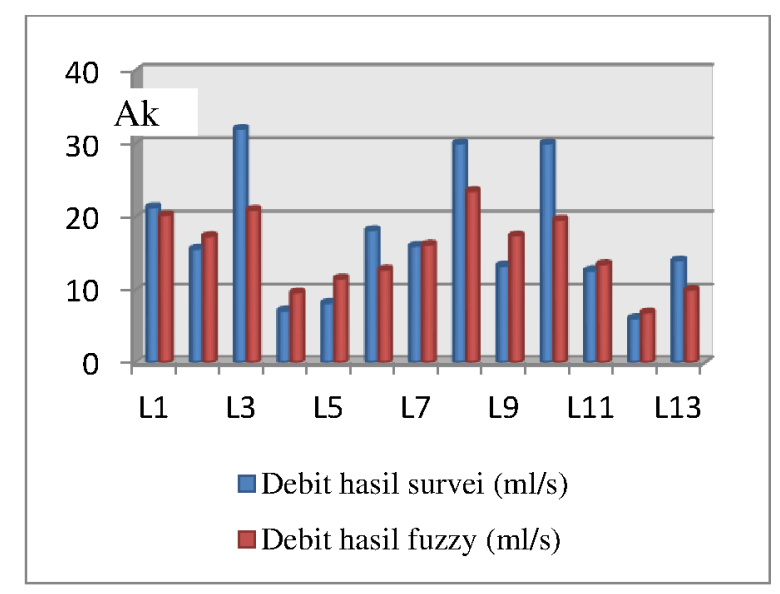

Gambar 11 Perbandingan data debit mata airlapangan dengan data debit airhasil fuzzy

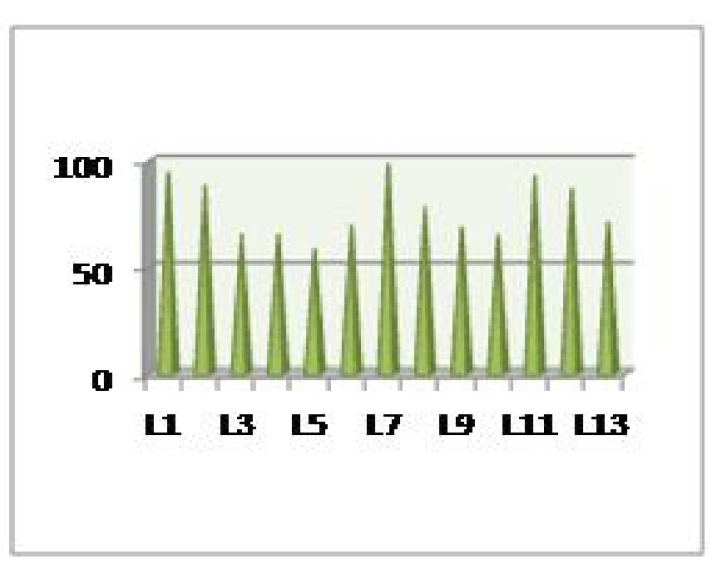

Gambar 12 Perbandingan akurasi metodefuzzy pada seluruh data survey lapangan

Di lain pihak, tingginya akurasi tiga lokasi yaitu L1 dengan akurasi 94.98\%, L7 dengan akurasi $98.81 \%$, dan L11 dengan akurasi $93.44 \%$ diperkirakan terjadi karena pengukuran yang tepat pada saat survei lapangan dan tingkat akurasi metode fuzzy Sugeno yang baik. Konsep rule fuzzy bahwa semakin tinggi nilai input maka semakin tinggi juga nilai debit mata air (output) juga dinilai benar karena menghasilkan tiap data yang akurasinya melebihi $50 \%$.

Rata-rata akurasi dari keseluruhan data adalah $77.53 \%$. Tentu saja rata-rata akurasi akan berubah jika datanya ditambah ataupun dikurangi karena itu penulis tidak menjadikan rata-rata akurasi sebagai ukuran melainkan melihat dari akurasi tiap data yang secara keseluruhan melebihi $50 \%$.

\section{Pengembangan Aplikasi}

Aplikasi yang dikembangkan memberikan kemudahan dalam proses pencarian mata air yang berkualitas pada aspek debit mata air dengan cara menduga debit mata air pada suatu wilayah. Semakin tinggi debit mata air dugaan pada suatu wilayah maka semakin baik wilayah tersebut untuk dijadikan sumber mata air baru. Input dari aplikasi adalah nama kelurahan dan keterangan daerah, jumlah tanaman (dalam satuan batang), tinggi muka air tanah (dalam satuan meter), dan besar sudut topografi (dalam satuan derajat) pada wilayah yang diinginkan. Output dari aplikasi adalah debit mata air dugaan danpeta administrasi kota Bogor yang berfungsi sebagai pencarian data berdasarkan kelurahan yang ada di peta.

\section{SIMPULAN}

Penelitian ini mengukur kesesuaian lahan untuk pendugaan debit mata air. Sistem yang dibangun memberikan kemudahan bagi masyarakat dalam pencarian mata air yang berkualitas. Dalam menduga debit mata air digunakan metode fuzzy Sugeno dengan fungsi keanggotaan input dan output diambil dari hasil analisis data survei lapangan dan rule dikembangkan sesuai dengan konsep dari pakar yaitu semakin tinggi nilai input karakterisitik lahan, maka semakin tinggi nilai debit mata airnya (output). 
Hasil evaluasi akurasi dapat disimpulkan bahwa konsep rule semakin tinggi nilai input maka semakin tinggi juga nilai output adalah benar karena hasil akurasi dari tiap data melebihi $50 \%$. Evaluasi juga memperlihatkan bahwa aplikasi ini layak dipakai. Sistem diharapkan dapat memberikan kontribusi positif untuk proses pencarian mata air dalam masyarakat luas.

Berdasarkan keterbatasan sistem maka terdapat beberapa hal yang diperlukan untuk pengembangan selanjutnya yaitu digunakannya karakterisitik lahan yang lebih banyak untuk aspek pendugaan debit mata air, data mata air yang dikumpulkan lebih banyak agar kisaran nilai untuk input fuzzy menjadi lebih besar dan bisa menjangkau wilayah yang lebih luas, dan adanya analisis tentang jumlah, bentuk, batas-batas fungsi keanggotaan fuzzy, dan rule fuzzy yang optimal sehingga hasil menjadi lebih akurat.

\section{DAFTAR PUSTAKA}

Anonim. 2001. Groundwater: A Primer for Pennsylvanians. Pennsylvania(US): Pennsylvania Water Resources Education Network (WREN).

Herusansono W, Suprihadi M. 2011. Tol baru Ungaran gusur mata air [Internet]. [diunduh 2011 Sep 17]. Tersedia pada: http://regional.kompas.com/read/2011/01/06/18440810/Tol.Baru. Ungaran.Gusur.Sumber.Mata.Air.

Joewono BN. 2011. Mata air hilang pasca letusan merapi [Internet]. [diunduh 2011 Sep 17]. Tersedia pada: http://regional.kompas.com/read/2011/03/04/14295424/Mata.Air.Hilang. Pasca.Letusan.Merapi.

Kusumadewi S. 2002. Analisis dan Desain Sistem Fuzzy Menggunakan Toolbox Matlab. Yogyakarta(ID): Graha Ilmu.

Nugrahanti AP, Joewono BN. 2011. Salatiga bukan kota mata air lagi [Internet]. [diunduh 2011

Sep 17]. Tersedia pada: http://regional.kompas.com/read/2011/04/25/20422188/Salatiga. Bukan.Kota.Mata.Air.Lagi.

Said NI. 2010. Daur ulang air limbah untuk air minum [Internet]. [diunduh 2011 Sep 16]. Tersedia pada: www.kelair.bppt.go.id/Publikasi/BukuAirMinum/BAB13DAUR.pdf 